\title{
Importance of Training for Companies in Serbia
}

\author{
Submitted 18/10/21, 1st revision 12/11/21, 2nd revision 28/11/21, accepted 10/12/21
}

\section{Ilir Morina ${ }^{1}$}

\begin{abstract}
:
Purpose: In an increasingly dynamic business environment and increased market competitiveness, quality and well-trained staff are vital to a company's success. Training is a process that gives employees new knowledge and skills needed to properly perform the work within the systems and standards set by management. The training includes transferring skills, knowledge, and information related to the job. New employees and even experienced workers need proper training to ensure that their job performance meets company standards. This paper aims to show the importance of employee training for the productivity and profitability of companies in Serbia.

Design/Methodology/Approach: To determine whether companies in Serbia train their employees, this paper uses primary data sources obtained as a result of a survey conducted in 40 companies in Serbia. The questionnaire consisted of seven questions related to the type of training, the location of the training, the effects of the training, and the reasons why some companies do not train their employees. In each of these 40 companies, one of the top managers was interviewed, which means that the answer of one manager corresponds to the situation in the specific company in Serbia.

Findings: Noting the massive role of training for corporate success, most companies in Serbia conduct training for their employees. Most often, these trainings are performed within the company.

Practical Implications: This paper has proved the importance of training for the productivity and profitability of companies in Serbia.

Originality/Value: Using primary data sources obtained from a survey, this paper has proven the importance of training for the productivity and profitability of companies in Serbia.
\end{abstract}

Keywords: Training, Employee, Productivity, Enterprises, Serbia.

Research type: Research article.

\section{Introduction}

${ }^{1}$ Ph.D., University MB-Faculty of Business and Law-Beograd. Direction: Management, ilirmorina@hotmail.com; 
In an increasingly dynamic business environment and increased market competitiveness, quality and well-trained staff are vital elements of a company's success. In the literature, the term training is often equated with employee development. However, a distinction must be made between these two similar terms. Development has often been seen as being much more about the growth or realization of a person's ability through conscious or unconscious learning. Development programs also include planned study and experience elements and are frequently supported by a coaching or counseling facility. In that sense, training is often perceived as being for non-managerial staff, while development is the preserve of managers. The ultimate goal of the training is to focus on the employee's current work, while the development focuses on the potential advancement of the employee within the company.

\section{Literature Review}

\subsection{Training of Staff}

The training is a planned process to modify attitude, knowledge, or skill behavior through learning experience to achieve effective performance in an activity or range of activities. Its purpose is to develop the individual's abilities and satisfy the current and future workforce needs of the organization.

Training is a process that gives employees new knowledge and skills needed to properly perform the work within the systems and standards set by management. The training includes transferring skills, knowledge, and information related to the job. The training teaches the employees how to do their job, i.e., learning the necessary skills to perform the work according to the established standards. New employees and even experienced workers need proper training to ensure that their job performance meets company standards.

There are many methods that organizations can use to train and develop staff. There is no one 'best' training method because these various methods have both strengths and weaknesses. Although there are many training methods, generally, all these methods can be categorized into three types of training: in-company on-the-job, incompany off-the-job, and external off-the-job.

In-company, on-the-job training involves watching and observing somebody with more excellent experience performing a task. This is a prevalent method of training where new skills and methods are taught to employees. On-the-job training is probably one of the most commonly used training techniques. This type of training is delivered directly to the employee while on the job. The advantages of this type of training are that it is cheap, the trainees can practice immediately, trainees get immediate feedback, and it can also help integrate trainees into existing teams. Job rotation or cross-training is another effective training method widely used in companies. To cross-train 
employees in various jobs, supervisors will often move the trainee from job to job. This training method is effective because it gives workers the ability to perform a variety of jobs at the workplace and sometimes helps to eliminate the potential for boredom. It helps to provide employees with exposure to various jobs and provides management with greater flexibility when assigning tasks. Cross-training also enables management to run a smooth operation when employees are on vacation or absent because cross-trained employees can step in and perform the tasks of the absent employee. Cross-training also helps employees develop skills and acquire knowledge that may lend themselves well to potential career advancements.

A variant of this type of training is mentoring, wherein a senior experienced member of staff takes responsibility for the development and progression of selected individuals. The trainee observes the skills displayed by the mentor and learns from their experience. Ordinarily, this type of training is used for managerial staff, and the selected individual is often somebody who has aspirations to reach senior management levels.

In-company, off-the-job training takes place outside of the employee's usual place of work. These training methods do not necessarily occur entirely away from the workplace. This type of training will often involve a training intervention run by a specialized training department. There is a wide array of methods in this type of training, such as lectures, case studies, video presentations, role plays, simulation exercises, e-learning, computer-based training, self-study, etc.

External, off-the-job type of training is undertaken outside the organization. There are various training methods such as taking courses, outward bound courses, outdoor training, etc.

\subsection{The Positive Effects of Training}

Training plays a key role in the success of the whole enterprise. The training benefited both the employees and the managers, but also the whole organization.

According to Sommerville (2007) these benefits can be grouped as follows:

Training benefits the employee:

1. Increases job satisfaction and recognition.

2. Moves employee closer to personal goals.

3. Encourages self-development and self-confidence.

4. Helps the employee become an effective problem solver.

5. Allows employee to become productive more quickly.

6. Sustains a positive attitude toward customer service.

Training benefits management:

1. Improves communication between managers and employees. 
2. Improves morale and builds cohesiveness between managers and employees.

3. Aids in evaluating employee performance.

4. Makes policies and procedures viable.

5. Aids in sustaining systems and standards.

6. Helps to identify employees for promotions or transfers.

Training benefits the organization:

1. Leads to improved profitability.

2. Reduces accidents and safety violations.

3. Helps create a positive corporate image.

4. Aids in organizational development.

5. Assists in developing employees for internal promotions.

6. Helps employees adjust to change.

7. Reduces costly employee turnover.

\subsection{Vocational Education and Staff Training in Serbia}

Serbia's vocational education and training scores are like the Western Balkan average. Professionally oriented education starts at the upper secondary level, when students are allocated into either general, vocational, or art programs based on their academic performance in lower secondary school, resulting in a national exam and individual preferences. Most upper secondary students in Serbia (74\% as of 2018) enrol in vocational upper secondary schools, much higher than the EU (485) and OECD (32\%) (World Bank, 2020).

However, evidence from PISA finds that learning outcomes across vocational education and training and general education tracks are not equal, as vocational students tend to have weaker literacy and numeracy skills than their peers in general education. While many education systems struggle with this challenge, Serbia has the widest gap in reading performance ( 85 score points) between vocational and general students (OECD, 2020). Moreover, socio-economically disadvantaged students in Serbia are more than five times as likely to attend a vocational upper secondary school, suggesting that the current sorting mechanism may reflect students' background more than their capability (OECD, 2020).

The Serbian government recently passed a set of by-laws to better plan and coordinate career guidance activities across the education system. It introduced a set of standards for career guidance practitioners in 2019, and Career Guidance and Counselling Teams were extended to vocational schools offering dual education (Government of Serbia, 2019). This is a positive development considering that data from the Ministry of Youth and Sports found that some 50\% of youth report having never taken part in career guidance and counselling activities (CeSID, 2019).

Serbia collects and disseminates data about the vocational education and training system, such as enrolment and completion rates, to inform career pathways and policy development. There is also some information about labour market outcomes. For 
example, at around 53,6\%, vocational education and training graduates (20-34 - olds) in Serbia is lower than the EU average of $76,8 \%$ (EC, 2020). While this type of information can be helpful, other labour market information is limited. For example, there is no information on the number of learners hired after completing an apprenticeship or WBL opportunity, nor are they any earnings data. Serbia plans to collect these data once its new education management information system (EMIS) is fully developed, but such mechanisms are not yet in place.

Serbia has started to move away from its previous theoretical model of vocational education toward more work-based learning (ETF, 2018). The government started implementing a dual model for vocational education in 2019, whereby students attend regular classes in school and take part in work-based learning experiences outside of the classroom. The Law on Dual Education clearly defines all aspects of WBL and requires that curricula include compulsory general, vocational, and elective subjects. This could help ensure that all students develop the core literacy and numeracy skills needed to succeed in the workplace and adjust to the labour market changes.

Serbia's score in tertiary education is lower than the Western Balkan 6 average. While the EU has set a goal of having $15 \%$ of the population aged $25-64 \%$ participate in lifelong learning and adult education by 2020, Serbia's strategic commitment is to reach at least 7\% (MoESTD, 2018). The Serbian tertiary education sector is primarily public (66\% in 2018), with a stable share of private institutions. The sector has expanded over the past decade, and national data show that nearly $22 \%$ of adults (aged 25 and over) have attained some form of tertiary education. However, this is still behind the OECD average of $45 \%$ (OECD, 2020) and access to tertiary education in Serbia remains a challenge for individuals from vulnerable social groups (MoESTD, 2018).

Serbia has taken several steps to improve the labour market relevance of higher education in recent years. This topic is expected to be a priority in the following institutions to have a Council of Employers to help strengthen links between the labor market and the education system.

Despite these efforts, there is evidence that skill shortages extend across most sectors of the economy, and Serbia's share of 15-24-year-olds who are not in employment, education, or training is higher than OECD and EU averages. Overall, Serbia's unemployment rate remains high, especially among young adults and recent tertiary graduates (Eurostat, 2020). This contributes to outgoing migration as skilled young people search for better opportunities abroad and, when combined with Serbia's decreasing population, presents a risk to economic competitiveness.

The level of education significantly determines labour market outcomes. Low educational attainment is associated with a higher risk of informal employment. Employment growth has been driven by a rise in employment among both low and highly educated workers. The unemployment rates fell for workers with all levels of education each year between 2015 and 2018 (and 2019 Q2); among low-educated 
workers, they fell from 15\% to 12,1\% in 2018 (and 9,2\% in Q2 2019); among mediumeducated workers from $19,4 \%$ to $13,7 \%(11,4 \%$ in Q2 2019) and highly-educated workers from $15,3 \%$ to $10,8 \%$ (8,5\% in Q2 2019). The most robust percentage-point reduction in unemployment was among the medium educated, followed by the highly educated (WIIW and World Bank, 2020). The proportion of young people not in employment, education, or training (NEET) stood at 15, 3\% in 2019, down from 19, $9 \%$ in 2015 (SORS, 2020).

Despite improvements in labour market outcomes, skills mismatches continue to be a significant challenge. The employment rate among recent graduates (20-34-year-olds) was 56, 9\% in 2017, well below the EU average of around $80 \%$ (European Commission, 2019). Employers name lack of work experience as one barrier to recruitment and generally indicate they face a shortage of candidates with the skills they need, according to a survey conducted by the National Employment Service (NES), Serbia's public employment service. Over-education is another pressing issue.

Over-education may result from an oversupply of university graduates and skills among young graduates if they do not acquire the technical and soft skills employers need and weaknesses in the education-to-work transition. Graduates' first work experience may thus be in a job requiring a much lower formal education level.

Serbia has taken significant steps towards improving its skills framework. It adopted the National Qualification Framework for Serbia in 2018 and established a link to the European Qualification Framework. Efforts have been undertaken since 2016 to introduce work-based learning elements into VET, and the corresponding legislative provisions were completed in 2018. The system is still in its pilot stage, and the first evaluation results will become available in 2021. Efforts should then be undertaken to introduce quality assurance mechanisms. Career guidance is being improved as part of the National Employment Action Plan. More efforts are needed to make career guidance sensitive to reduce gender imbalances in some professions, as well as to develop career guidance for adults.

Participation in adult learning is low. According to data from the Adult Education Survey of 2016, 19,8\% of adults participated in some non-formal education or training in 2016, an increase in 2011, but still well below the EU average of 45,1\% (SORS, 2018). Participation in Serbia was higher than in other economies in the region for which information is available (Albania, Bosnia and Herzegovina, and North Macedonia). Employees participate the most in education and training (32.5\% of all employees) (Table 1). The participation rate was highest among young adults (25-34), particularly highly educated urban women. For the most part, training was workrelated and performed at work, during working hours, and paid for by employers. Types of non-formal education activities related to work are the instruction at work $67.4 \%$; workshop or seminar $24.3 \%$; course $8.2 \%$ and private lessons $0.1 \%$. Almost half of the respondents (47\%) wanted to participate in adult learning but could not be 
due to the costs of education/training, family reasons, scheduling (i.e., overlapping with working hours), and lack of suitable training.

Most respondents participate in some form of informal learning. About two-thirds of them acquire new knowledge using a computer (65.8\%); 63.6\% learn from family members, friends, or colleagues, and about $60 \%$ from television/radio or video. To a significant extent $(57.5 \%)$, respondents also learn from printed materials (books, professional journals, etc.), and to a lesser extent by visiting museums, libraries, learning centers, etc. The Strategy for Education Development in Serbia, adopted in 2012, aimed to increase the education offer for adults by 2020. More efforts are needed to increase participation in continuing training of prime-age and older workers and among those who are medium and low-educated, vulnerable groups, and the selfemployed. Adult education, lifelong learning opportunities, and second-chance education for adults are not enough to improve the labour market integration of vulnerable groups. There is little coordination between public and private institutions implementing education and training policies for labour market integration and social inclusion.

Table 1. Adult participation in non-formal education and training (\%)

\begin{tabular}{|c|c|c|c|c|}
\hline & & Total & Men & Women \\
\hline Total & & 19,8 & 18,0 & 21,4 \\
\hline \multirow[t]{3}{*}{ Age groups } & $25-34$ & 29,2 & 26,2 & 32,4 \\
\hline & $35-49$ & 23,5 & 21,3 & 25,7 \\
\hline & $50-64$ & 10,5 & 9,6 & 11,4 \\
\hline \multirow{3}{*}{$\begin{array}{l}\text { Highest completed } \\
\text { education }\end{array}$} & Primary Education & I & 1 & I \\
\hline & Secondary education & 14,2 & 13,7 & 14,7 \\
\hline & Faculty & 39,9 & 35,4 & 43,6 \\
\hline \multirow[t]{3}{*}{ Employment Status } & Employed & 32,5 & 26,9 & 39,1 \\
\hline & Unemployed & 11,0 & 10,2 & 11,8 \\
\hline & Inactive & 9,8 & 11,4 & 8,7 \\
\hline \multirow{3}{*}{$\begin{array}{l}\text { Degree } \\
\text { urbanization }\end{array}$} & Cities & 27,3 & 24,7 & 29,6 \\
\hline & Smaller towns and suburbs & 21,0 & 19,9 & 22,2 \\
\hline & Rural areas & 12,7 & 11,6 & 13,8 \\
\hline
\end{tabular}

Source: Adult Education Survey-AES, 2016.

\section{Research Methodology}

In order to determine whether companies in Serbia train their employees, this paper uses primary data sources obtained as a result of a survey conducted in 40 companies in Serbia. The questionnaire consisted of seven questions related to the type of training, the location of the training, the effects of the training, and the reasons why some companies do not train their employees. In each of these 40 companies, one of the top managers was interviewed, which means that the answer of one manager corresponds to the situation in the specific company in Serbia.

\section{Results}


Regarding the first question, Do you train your employees? the results are presented in Table 2. As shown in Table 2, the managers of 37 companies in Serbia answered that they train their employees, and the other 3 managers answered that they do not train employees. Descriptive statistics and frequency in Tables 3-4.

Table 2. Do you train your employees?

\begin{tabular}{|l|r|r|}
\hline Responseto question number $\mathbf{1}$ & Number of managers & \multicolumn{1}{|c|}{$\%$} \\
\hline Yes & 37 & 92,50 \\
\hline No & 3 & 7,50 \\
\hline Total & $\mathbf{4 0}$ & $\mathbf{1 0 0}$ \\
\hline
\end{tabular}

Source: Adult Education Survey-AES, 2016.

Table 3. Descriptive statistics for the first question

\begin{tabular}{|l|l|}
\hline Min & 1 \\
\hline Max & 2 \\
\hline Range & 1 \\
\hline Size & $\mathrm{n}=40$ \\
\hline Sum & 43 \\
\hline Mean & 1,075 \\
\hline Median & 1 \\
\hline Mode & 1 \\
\hline Standard deviation & 0.266746783 \\
\hline Coefficient of variation & $\mathrm{CV}=0.248136542$ \\
\hline
\end{tabular}

Source: Adult Education Survey-AES, 2016.

Table 4. Frequency table

\begin{tabular}{|l|l|l|}
\hline Value & Frequency & Frequency $\%$ \\
\hline 1 & 37 & 92,50 \\
\hline 2 & 3 & 7,50 \\
\hline
\end{tabular}

Source: Own creation.

Most companies in Serbia train their employees in their companies, i.e., in the workplace during the work process. A few companies provide training outside their companies, inappropriate places for that, and professionals (Table 5). Descriptive statistics and frequency in Tables 6-7.

Table 5. Places where training was conducted

\begin{tabular}{|l|r|r|}
\hline Response to question number 2 & Number of managers & \multicolumn{1}{|c|}{$\%$} \\
\hline In our company & 35 & 94,59 \\
\hline Outside our company & 2 & 5,41 \\
\hline Total & $\mathbf{3 7}$ & $\mathbf{1 0 0}$ \\
\hline
\end{tabular}

Source: Adult Education Survey-AES, 2016.

Table 6. Descriptive statistics for the second question

\begin{tabular}{|l|l|}
\hline Min & 1 \\
\hline
\end{tabular}




\begin{tabular}{|l|l|}
\hline Max & 2 \\
\hline Range & 1 \\
\hline Size & $\mathrm{n}=37$ \\
\hline Sum & 39 \\
\hline Mean & 1.05405405 \\
\hline Median & 1 \\
\hline Mode & 1 \\
\hline Standard deviation & 0.229243435 \\
\hline Coefficient of variation & $\mathrm{CV}=0.217487362$ \\
\hline
\end{tabular}

Source: Adult Education Survey-AES, 2016.

Table 7. Frequency table

\begin{tabular}{|l|l|l|}
\hline Value & Frequency & Frequency $\%$ \\
\hline 1 & 35 & 94,59 \\
\hline 2 & 2 & 5,41 \\
\hline
\end{tabular}

Source: Adult Education Survey-AES, 2016.

Most often, the training is performed for beginners, ie new employees who start working in the company, and a small number of companies provide regular training to all their employees (Table 8). Descriptive statistics and frequency in Tables 9-10.

Table 8. If you are training employees, please indicate what type of training you are conducting

\begin{tabular}{|l|r|r|}
\hline Response to question number 3 & Number of managers & \multicolumn{1}{|c|}{$\%$} \\
\hline Training for beginners & 30 & 81,08 \\
\hline Regular training for all employees & 7 & 18,92 \\
\hline Total & $\mathbf{3 7}$ & $\mathbf{1 0 0}$ \\
\hline
\end{tabular}

Source: Adult Education Survey-AES, 2016.

Table 9. Descriptive statistics for the third question

\begin{tabular}{|l|l|}
\hline Min & 1 \\
\hline Max & 2 \\
\hline Range & 1 \\
\hline Size & $\mathrm{n}=37$ \\
\hline Sum & 44 \\
\hline Mean & 1.18918919 \\
\hline Median & 1 \\
\hline Mode & 1 \\
\hline Standard deviation & 0.397061277 \\
\hline Coefficient of variation & $\mathrm{CV}=0.333892437$ \\
\hline
\end{tabular}

Source: Adult Education Survey-AES, 2016.

Table 10. Frequency table

\begin{tabular}{|l|l|l|}
\hline Value & Frequency & Frequency $\%$ \\
\hline 1 & 30 & 81,08 \\
\hline 2 & 7 & 18,92 \\
\hline
\end{tabular}


Source: Adult Education Survey - AES, 2016.

All managers of companies that train their employees to agree that training improves employee performance and increases their profitability (Tables 11, 12, 13), and increases cohesion between employees and managers (Table 14).

Table 11. Does employee training increase your company's profitability?

\begin{tabular}{|l|r|r|}
\hline Response to question number 4 & Number of managers & \multicolumn{1}{|c|}{$\%$} \\
\hline Yes & 37 & 92,50 \\
\hline No & 0 & 0 \\
\hline I do not know & 3 & 7,50 \\
\hline Total & $\mathbf{4 0}$ & $\mathbf{1 0 0}$ \\
\hline
\end{tabular}

Source: Adult Education Survey - AES, 2016.

Table 12. Descriptive statistics for the for the fourth, fifth and sixth questions

Source: Adult Education Survey - AES, 2016.

\begin{tabular}{|l|l|}
\hline Min & 1 \\
\hline Max & 2 \\
\hline Range & 1 \\
\hline Size & $\mathrm{n}=40$ \\
\hline Sum & 43 \\
\hline Mean & 1,075 \\
\hline Median & 1 \\
\hline Mode & 1 \\
\hline Standard deviation & 0.266746783 \\
\hline Coefficient of variation & $\mathrm{CV}=0.248136542$ \\
\hline
\end{tabular}

Table 13. Frequency table

\begin{tabular}{|l|l|l|}
\hline Value & Frequency & Frequency $\%$ \\
\hline 1 & 37 & 92,50 \\
\hline 2 & 3 & 7,50 \\
\hline
\end{tabular}

Source: Own creation.

Table 14. Does employee training build cohesion between managers and employees?

\begin{tabular}{|l|r|r|}
\hline Response to question number 5 & Number of managers & \multicolumn{1}{|c|}{$\%$} \\
\hline Yes & 37 & 92,50 \\
\hline No & 0 & 0 \\
\hline I do not know & 3 & 7,50 \\
\hline Total & $\mathbf{3 3}$ & $\mathbf{1 0 0}$ \\
\hline
\end{tabular}

Source: Adult Education Survey-AES, 2016.

All managers of companies that train their employees to improve employee performance and increase their profitability (Table 15). 
Table 15. Does employee training improve employee performance and increase their productivity?

\begin{tabular}{|l|r|r|}
\hline Response to question number 6 & Number of managers & \multicolumn{1}{|c|}{$\%$} \\
\hline Yes & 37 & 92,50 \\
\hline No & 0 & 0 \\
\hline I do not know & 3 & 7,50 \\
\hline Total & $\mathbf{3 3}$ & $\mathbf{1 0 0}$ \\
\hline
\end{tabular}

Source: Adult Education Survey - AES, 2016.

A small number of companies in Serbia do not provide any training to their employees. Reasons for this are: they hire experienced and trained workers who do not need training, staff training costs a lot of money and time, and companies in Serbia do not have the resources needed to train employees (Table 16). Descriptive statistics and frequency in Tables 17 and 18.

Table 16. If you do not train your staff, please state the reasons for that:

\begin{tabular}{|l|r|r|}
\hline Response to question number 7 & Number of managers & \multicolumn{1}{|c|}{} \\
\hline $\begin{array}{l}\text { Our employees do not need training } \\
\text { because we usually hire experienced } \\
\text { and trained workers }\end{array}$ & 1 & 33,33 \\
\hline $\begin{array}{l}\text { We believe that staff training is not } \\
\text { necessary }\end{array}$ & 0 & 0 \\
\hline Training costs a lot of money and time & 1 & 33,33 \\
\hline $\begin{array}{l}\text { We do not have the resources needed } \\
\text { to train employees }\end{array}$ & 1 & 33,33 \\
\hline Total & $\mathbf{3}$ & $\mathbf{1 0 0 \%}$ \\
\hline
\end{tabular}

Source: Adult Education Survey - AES, 2016.

Table 17. Descriptive statistics for the for the seventh question

Source: Own creation.

\begin{tabular}{|l|l|}
\hline Min & 1 \\
\hline Max & 4 \\
\hline Range & 3 \\
\hline Size & $\mathrm{n}=3$ \\
\hline Sum & 8 \\
\hline Mean & 2.666666 \\
\hline Median & 3 \\
\hline Mode & $1,3,4$ \\
\hline Standard deviation & 1.52752523 \\
\hline Coefficient of variation & $\mathrm{CV}=0.572821962$ \\
\hline
\end{tabular}

Table 18. Frequency table

\begin{tabular}{|l|l|l|}
\hline Value & Frequency & $\begin{array}{l}\text { Frequency } \\
\%\end{array}$ \\
\hline
\end{tabular}




\begin{tabular}{|l|l|l|}
\hline 1 & 1 & 33.33 \\
\hline 3 & 1 & 33.33 \\
\hline 4 & 1 & 33.33 \\
\hline
\end{tabular}

Source: Adult Education Survey-AES, 2016.

Cross analysis of the answers to questions $1,4,5$ and 6 gives the following results:

Table 19. Regression

\begin{tabular}{|l|l|l|l|l|l|}
\hline & $\mathrm{df}$ & $\begin{array}{l}\text { Sum of } \\
\text { Square }\end{array}$ & $\begin{array}{l}\text { Mean } \\
\text { Square }\end{array}$ & $\begin{array}{l}\mathrm{F} \text { statistic } \\
\left(\mathrm{df}_{1}, \mathrm{df}_{2}\right)\end{array}$ & $\begin{array}{l}\text { P- } \\
\text { Value }\end{array}$ \\
\hline $\begin{array}{l}\text { Regression } \\
\left.\text { (between } \hat{y}_{\mathrm{i}} \text { and } \bar{y}\right)\end{array}$ & 1 & 11.1 & 11.1 & $\begin{array}{l}\text { Infinity } \\
(1,38)\end{array}$ & NaN \\
\hline $\begin{array}{l}\text { Residual (between } \mathrm{y}_{\mathrm{i}} \text { and } \\
\left.\hat{y}_{\mathrm{i}}\right)\end{array}$ & 38 & 0 & 0 & & \\
\hline Total (between $\mathrm{y}_{\mathrm{i}}$ and $\left.\overline{\mathrm{y}}\right)$ & 39 & 11.0 & 0.2846 & & \\
\hline
\end{tabular}

Source: Adult Education Survey - AES, 2016.

$\mathrm{R}$ Square $\left(\mathrm{R}^{2}\right)$ equals 1 . It means that $100 \%$ of the variability of $\mathrm{Y}$ (company's profitability; cohesion between managers and employees; and improve employee performance and increase their productivity) is explained by $\mathrm{X}$ (staff training). Correlation $(\mathrm{R})$ equals 1 . It means that there is a very strong i.e., ideal direct relationship between $\mathrm{X}$ and $\mathrm{Y}$.

All this shows that the training of employees is of great importance for employees, managers and the company itself.

\section{Conclusions}

Training is a process that gives employees new knowledge and skills needed to properly perform the work within the systems and standards set by management. The training includes transferring skills, knowledge, and information related to the job. New employees and even experienced workers need proper training to ensure that their job performance meets company standards. There are many methods that organizations can use to train and develop staff. There is no one 'best' training method because these various methods have both strengths and weaknesses.

Although there are many training methods, generally, all these methods can be categorized into three types of training: in-company on-the-job, in-company off-thejob, and external off-the-job. The training benefited both the eemployees and the managers and the whole organization. Noting the importance of training for corporate success, most companies in Serbia train their employees. Most often, these trainings are performed within the company. A small number of companies in Serbia do not provide any training to their employees. Reasons for this are, they hire experienced and trained workers who do not need training, staff training costs a lot of money and time, and companies in Serbia do not have the resources needed to train employees. 


\section{References:}

Berkley, R.A., Kaplan, D.M. 2019. Strategic Training and Development, SAGE Publication. Bhattacharyya, D.K. 2015. Training and Development - Theories and Applications, SAGE.

Hindson, A.C. 1994. Training and development: Management attitudes and practices in the New Zealand Hotel Industry.

Hyman, J. 2017. Training at Work: Critical Analysis of Workplace Training and Development. Taylor \& Francis Group.

Kirkpatrick, D.L. 2006. Improving Employee Performance through Appraisal and Coaching, American Management Association.

Kovaci, I., Tahiri, A., Bushi, F., Zhubi, M. 2021. Organization as a Function of Management and the Types of Organizational Structures that Apply in SMEs in Kosovo. Quality Access to Success, 22(181).

Kozlowski, S.W.J., Salas, E. 2010. Learning, Training, and Development in Organizations, Routledge.

Lorković, D. 2018. Obrazovanje I Razvoj Kadrova Kao Sastavnica Menadžmenta [Education and Human Resources Development As A Component Of Management]. University of Applied Sciences / Veleučilište u Karlovcu.

Nelson, E. 2021. Management Development - training, ATD Press.

Noe, R.A. 2005. Employee Training and Development, McGraw-Hill Education.

Noe, R.A. 2016. Employee Training \& Development, McGraw-Hill Education.

Ross, S.C. 2018. Training and Development in Organizations: An Essential Guide for Trainers. Taylor \& Francis.

Saks, A.M., Haccoun, R.R. 2012. Managing Performance Through Training and Development. Nelson Education Limited.

Sommerville, К.Л. 2007. Hospitality employee management and supervision - concepts and practical applications. John Wiley \& Sons, Inc.

Tahiri, A., Kovaçi, I., Bushi, F., Meha, A. 2021. Decision making and the applying of decision-making techniques in SMEs in Kosovo. Quality Management, (22)180.

Tahiri, A., Kovaçi, I., Krasniqi, A. 2021. Appraisal of Human Resource Management. Performance Management and Employee Performance by SME Managers in Kosovo,

United Nations. 2013. Human Resources Management and Training - Compilation of good practices in statistical offices.

Wentland, D.M. 2007. Strategic Training: Putting Employees First. 